\title{
Restoring tallgrass prairie species mixtures on leafy spurge-infested rangeland
}

\author{
ROBERT A. MASTERS, DANIEL D. BERAN, AND ROCH E. GAUSSOIN
}

Authors are field development biologist, Dow AgroSciences, 3618 South $75^{\text {th }}$ Street, Lincoln, Nebr. 68506, market development specialist, BASF, 1422 57 th, Place, Des Moines, Iowa, and extension turfgrass specialist, Department of Agronomy and Horticulture, University of Nebraska, Lincoln, Nebr. 68583. At time of this research, Masters was rangeland scientist, USDA-ARS, 344 Keim Hall, University of Nebraska, Lincoln, Nebr. 68583 and Beran was research assistant, Department of Agronomy and Horticulture, University of Nebraska, Lincoln, Nebr. 68583.

\section{Abstract}

Leafy spurge (Euphorbia esula L.) reduces northern Great Plains rangeland carrying capacity. Treatment strategies were evaluated that suppressed leafy spurge and facilitated establishment of mixtures of native grasses and legumes on range sites near Mason City and Tilden, Nebr. Glyphosate at 1,600 $\mathrm{g}$ a.i. (active ingredient) $\mathrm{ha}^{-1}$ was applied with or without imazapic at 140 or 210 g a.i. ha ${ }^{-1}$ in October 1995. In April 1996, standing crop was burned or mowed. Mixtures of native grasses [big bluestem (Andropogon gerardii Vitman), indiangrass (Sorghastrum nutans (L.) Nash), switchgrass (Panicum virgatum L.), little bluestem (Schizachyrium scoparium (Michx.) Nash), and sideoats grama (Bouteloua curtiplendula (Michx.) Torr.)] were then planted with or without native legumes [leadplant (Amorpha canescens (Nutt.) Pursh), Illinois bundleflower (Desmanthus illinoensis (Michx.) MacM.), and purple prairieclover (Petalostemum purpureum (Vent.) Rybd.)] at $\mathbf{4 4 0}$ pls $\mathrm{m}^{-2}$ into a non-tilled seedbed. Imazapic was applied at $70 \mathrm{~g}$ a.i. ha $^{-1}$ in June 1996 to half the plots that had been treated with imazapic in October 1995. Frequency, dry matter yield, and leafy spurge density were measured 14 to 16 months after planting. Leafy spurge density and yield were least, and frequencies and yields of the planted grasses usually were greatest where imazapic had been applied with glyphosate in October 1995. Purple prairieclover was the only planted legume to persist 14 months after planting, and yields were greatest where imazapic was applied with glyphosate. Imazapic applied in June 1996 usually did not improve planted species yields or leafy spurge control. Total vegetation yields were greater where imazapic was applied with glyphosate at both sites and where native species were seeded at Mason City. Vegetation suppression with fallapplied herbicides and removal of standing crop enabled successful establishment of desirable species, increased forage yields, and suppressed leafy spurge.

Key Words: Prescribed fire, grassland restoration, imazapic, glyphosate, warm-season grasses, cool-season grasses, legumes, invasive plants

Research was funded in part by American Cyanamid, Monsanto, University of Nebraska Foundation-Arthur Sampson Range and Pasture Management Endowment Fund, and United States Environmental Protection Agency. The authors thank Kevin Grams, Fernando Rivas-Pantoja, and Ken Carlson for their assistance with plot installation and sampling. This paper is a joint contribution of the USDA-ARS and the Nebraska Agriculture Research Division Journal Series No. 13133.

Manuscript accepted 30 Sept. 00.

\section{Resumen}

El 'Leafy spurge (Euphorbia esula L.) reduce la capacidad de carga de los pastizales del norte de las Grandes Planicies. Se evaluaron estrategias de tratamiento que suprimen el "Leafy spurge" y facilitaron el establecimiento de mezclas de zacates nativos y leguminosas en sitios de pastizal cercanos a Mason City, Nebr. En Octubre de 1995 se aplico Glifosato en dosis de $1600 \mathrm{~g}$ i.a. (i.a. = ingrediente activo) con y sin Imazapic en dosis de 140 o $210 \mathrm{~g}$ i.a. $\mathrm{ha}^{-1}$. En Abril de 1996 el forraje en pie fue segado o quemado y después se plantaron mezclas de zacates nativos ["Big bluestem" (Andropogon gerardii Vitman), "Indiangrass" (Sorghastrum nutans (L.) Nash), "Switchgrass", (Panicum virgatum L.), "Little bluestem" (Schizachyrium scoparium (Michx.) Nash), and "Sideoats grama" (Bouteloua curtiplendula (Michx.) Torr.)] con y sin leguminosas nativas ["Leadplant" (Amorpha canescens (Nutt.) Pursh), "Illinois bundleflower" (Desmanthus illinoensis (Michx.) MacM.), and "Purple prairieclover" (Petalostemum purpureum (Vent.) Rybd.)]

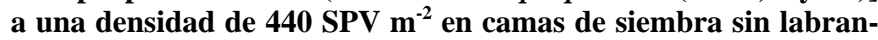
za. En Junio de 1996 a la mitad de las parcelas que en Octubre de 1995 habían sido tratadas con Imazapic se les aplico Imazapic a una dosis de $70 \mathrm{~g}$ i.a ha ${ }^{-1}$. Después de 14 a 16 meses de la siembra se midió la frecuencia, densidad y rendimiento de materia seca de "Leafy spruge". La densidad y rendimiento de "Leafy spurge" fueron menores y las frecuencias y rendimientos de los zacates plantados usualmente fueron mayores en las áreas donde se aplico Imazapic con Glifosato en Octubre de 1995. La única leguminosa que persistió después de 14 meses de la siembre fue el "Purple prairieclover" y los rendimientos fueron mayores donde se aplico Imazapic con Glifosato. EI Imazapic aplicado en Junio de 1996 usualmente no mejoro los rendimientos de las especies plantadas o el control de "Leafy spurge". Los rendimientos totales de la vegetación fueron mayores donde se aplico Imazapic con Glifosato, esto fue similar en ambos sitios y donde las especies nativas se sembraron en Manso City. La supresión de vegetación con herbicidas aplicados en otoño y la remoción de la vegetación en pie permitio el establecimiento exitoso de especies deseables, incrementó los rendimientos de forraje y suprimió el "Leafy spurge".

Leafy spurge (Euphorbia esula L.) is an invasive noxious weed that alters the function and structure of North American rangeland ecosystems. Leafy spurge was introduced from Eurasia into the northern Great Plains and prairie provinces of Canada in the 
late 1800s (Watson 1985) and now infests more than 1 million ha in North America (Dunn 1979). This invasive plant displaces native species (Belcher and Wilson 1989) and reduces livestock carrying capacity (Lym and Kirby 1987). Leafy spurge invasiveness is attributed to its ability to reproduce from seed, adventitious shoot buds on the crown and roots (Raju 1985), and the lack of natural enemies in North America (Harris et al. 1985). High seed yields and viability and rapid seedling development enable new infestations to establish quickly (Selleck et al. 1962). Past management practices appear to have hastened leafy spurge establishment and spread in the Great Plains (Masters et al. 1996).

Chemical and biological controls have been the primary means to manage leafy spurge. Long-term control of leafy spurge is possible with picloram (4-amino-3,5,6trichloro-2-pyridinecarboxylic acid) applied at $2.2 \mathrm{~kg}$ a.i. (active ingredient) $\mathrm{ha}^{-1}$ or greater rates (Lym and Messersmith 1985). The high cost of this treatment and concerns about surface water and groundwater contamination precludes picloram use on large infestations. Application of 2,4-D [(2,4-dichlorophenoxy)acetic acid $]+$ picloram at $1.1+0.28 \mathrm{~kg}$ a.i. $\mathrm{ha}^{-1}$ or $2,4-\mathrm{D}$ alone at $2.2 \mathrm{~kg}$ a.i. ha ${ }^{-1}$ provides short-term control of leafy spurge and reduces seed production. Imazapic \{2-[4,5-dihydro-4methyl-4-(1-methyl-ethyl)-5-oxo-1프-imidazol-2-yl]-5-methyl-pyridine carboxylic acid\}, applied in the fall for 2 consecutive years at $140 \mathrm{~g}$ a.i. $\mathrm{ha}^{-1}$ controlled more than $90 \%$ of the leafy spurge 11 to 12 months after the second application (Masters et al. 1998). The efficacy of imazapic results from high absorption, preferential translocation to roots and adventitious shoot buds, and slow rate of metabolism of this herbicide by leafy spurge (Thompson et al. 1998). Biological control agents used against leafy spurge include goats (Lym et al. 1997), sheep (Landgraf et al. 1984), and insects (Hansen et al. 1997). Flea beetles reduced leafy spurge densities at some sites in North Dakota, but these reductions did not have a positive effect on grass yields (Kirby and Carlson 1998). Establishment of flea beetle populations has been highly variable in the northern Great Plains and factors responsible for this uneven success have not been identified (Lym 1998).

Historically, rangeland weed management research has emphasized development of chemical and biological control tactics. There is growing recognition that rangeland weed research should shift from the search for a single control technology to development of integrated strategies composed of multiple technologies used in sequences and combinations that optimize weed control and rangeland improvement (Scifres 1987). A goal of rangeland weed management should be to improve degraded rangeland communities so they are less susceptible to invasion by weeds (Masters et al. 1996, Sheley et al. 1996, Masters and Nissen 1998). Invasive plants appear to be a symptom of management problems that must be corrected before sustained progress can be made toward controlling weeds and improving rangeland productivity. Removing a weed species with chemical or biological controls may only provide an open niche for another undesirable species unless desirable species are present to occupy the vacated niche. In many instances, rangeland vegetation has deteriorated to the point that desirable species are either not present or in such low abundance that plant community recovery may not occur without revegetation with desirable species.

Approaches that include herbicide application and establishing monoculture stands of introduced or native perennial grasses have been used successfully to suppress leafy spurge and improve forage production on rangeland. In Wyoming, seedbed preparation consisted of multiple applications of glyphosate [N-(phosphonomethyl)glycine] in spring and summer followed by tillage before planting introduced cool-season grasses (Ferrell et al. 1998). Introduced cool-season grasses were planted in a tilled seedbed following application of glyphosate and 2,4-D in North Dakota (Lym and Tober 1997). The planted grasses that were most effective in suppressing leafy spurge were 'Bozoisky' Russian wildrye [Psathyrostachys juncea (Fisch.) Nevski] and 'Luna' pubescent wheatgrass [Elytrigia intermedia (Host) Beauv.] in Wyoming, and 'Rebound' smooth bromegrass (Bromus inermis L.) and 'Reliant' intermediate wheatgrass [Thinopyrum intermedium (Host) Barkw. \& D.R. Dewey] in North Dakota. In Nebraska, monoculture stands of native warm-season grasses, big bluestem (Andropogon gerardii Vitman), indiangrass [Sorghastrum nutans (L.) Nash], and switchgrass (Panicum virgatum L.), established on leafy spurge-infested rangeland increased herbage yields by more than $40 \%$ and reduced leafy spurge density and yield (Masters and Nissen 1998). The sites were treated with imazapyr \{2-[4,5-dihydro4-methyl-4-(1-methylethyl)-5-oxo-1H-imidazol-2-yl]-3-pyridinecarboxylic acid $\}$ and sulfometuron \{2-[[[[(4,6-dimethyl-2-pyrimidinyl)amino]carbonyl]amino]sulfonyl]ben zoic acid $\}$ in the fall and burned the following spring before tallgrasses were planted into the herbicide-suppressed sod without tillage. These studies demonstrate that leafy spurge-infested rangeland can be improved in the short-term by planting monoculture stands of desirable forage grasses; however, the rate of leafy spurge recovery and management required to maintain monoculture grass stands, while suppressing leafy spurge, has not been determined.

The focus of our rangeland improvement research effort was to develop integrated management strategies that suppress leafy spurge and associated vegetation, and facilitate planting and establishment of multiple native warm-season grass and legume species. Conceptually, multispecies assemblages should more fully use resources on degraded rangeland and more completely preempt resource use by less desirable species, including leafy spurge.

The purpose of this study was to determine if application of herbicides followed by mowing or burning the herbaceous standing crop could enhance establishment of planted mixtures of native species and reduce leafy spurge productivity. Glyphosate and imazapic were the herbicides selected to suppress leafy spurge and existing resident vegetation. Glyphosate controls cool-season grasses that are actively growing at the time of application, but provides no residual weed control. Imazapic provides residual control of leafy spurge, annual grasses, and broadleaf plants that would interfere with establishment of planted species. Imazapic is tolerated by a number of warm-season grasses (Rivas-Pantoja et al. 1997, Beran et al. 2000), forbs (Beran et al. 1999a) and legumes (Beran et al. 1999b). Herbaceous standing crop was removed to reduce the quantity of the plant residue that would otherwise interfere with no-till of planting desirable native species into the herbicidesuppressed sod.

\section{Materials and Methods}

Experiments were established on leafy spurge-infested rangeland near Mason City $\left(41^{\circ} 17^{\prime} \mathrm{N}, 99^{\circ} 17^{\prime} \mathrm{W}\right)$ and Tilden City $\left(42^{\circ} 00^{\prime} \mathrm{N}, 97^{\circ} 53^{\prime} \mathrm{W}\right)$, Nebr. The distance between the sites is about 150 $\mathrm{km}$, and Mason City and Tilden are located in south-central and northeastern Nebraska, respectively. These sites occur in the mixed-grass prairie region of the 
central Great Plains. Soil at Mason City was a Uly silt loam (mixed, mesic, Typic Haplustoll) and at Tilden was a Thurman fine sand (mixed, mesic, Udorthentic Haplustoll). The flora at both sites was dominated by leafy spurge, Kentucky bluegrass (Poa pratensis L.), and smooth bromegrass. Warm-season grasses at Mason City included buffalograss [Buchloe dactyloides (Nutt.) Engelm.], tall dropseed [Sporobolus asper (Michx.) Kunth], and red threeawn (Aristida longiseta Stued.). At Tilden, warm-season grasses included sand bluestem (Andropogon halli Hack.), big bluestem, sand dropseed [Sporobolus cryptandrus (Torr.) A. Gray], and blue grama [Bouteloua gracilis (H.B.K.) Lag. ex Steud.]. Both sites had a management history of moderate to heavy continuous grazing by cattle during spring and summer. Sites were not grazed or hayed during the study.

Experiments at both sites were designed as a randomized complete block arranged as a split-split plot with 4 replications per treatment combination. Standing crop management schemes were the main plot (10- by 48-m at Mason City and 16- by $30-\mathrm{m}$ at Tilden), herbicides were the subplot ( 8 - by $5-\mathrm{m}$ in size), and native plant mixtures were the sub-subplot (8- by 1.6$\mathrm{m}$ in size) treatments. At Mason City, the standing crop on 4 main plots was mowed to a $10 \mathrm{~cm}$ stubble height followed by removal with a dump rake on 3 April 1996 and was removed from the remaining 4 main plots by burning on 4 April 1996. At Tilden, the Kentucky bluegrass thatch that remained after mowing and raking the standing crop on 4 of the 8 main plots on 8 April 1996 was too heavy to allow penetration of the grass drill double disk openers during planting. This thatch layer was reduced on 9 April 1996 with a self-propelled dethatcher followed by raking. Standing crop was removed from the remaining main plots by burning on 17 April 1996. Main plots at both sites were burned according to Masters et al. (1990).

Herbicide treatments were applied to separate subplots in October 1995 and June 1996. Glyphosate at $1600 \mathrm{~g}$ a.i. ha ${ }^{-1}$ was applied alone or in combination with imazapic at 140 or $210 \mathrm{~g}$ a.i. $\mathrm{ha}^{-1}$ on 3 October 1995 at Mason City and 11 October 1995 at Tilden. Imazapic was applied at $70 \mathrm{~g}$ a.i. ha ${ }^{-1}$ on 19 June 1996 at Mason City and 17 June 1996 at Tilden to half the number of plots that had been treated with imazapic in October 1995. This treatment was used to determine if additional suppression of leafy spurge and less desirable warm-season grasses (red threeawn, sand dropseed, buffalograss, and blue grama) by imazapic applied in June 1996 would further enhance establishment of the planted species. Leafy spurge and cool-season grasses were growing, and warm-season grasses were dormant when herbicides were applied in October. Leafy spurge and cool-season grasses were flowering, while warm-season grasses were vegetative when herbicide was applied in June. Herbicides were applied in a total delivery volume of 187 liters $\mathrm{ha}^{-1}$ at $3 \mathrm{~km} \mathrm{hour}^{-1}$ and at $250 \mathrm{kPa}$ with a tractor-mounted, compressed-airpressurized sprayer. Methylated seed oil and $28 \%$ urea ammonium fertilizer, each at $1.25 \%(\mathrm{v} / \mathrm{v})$, were included in spray solutions to optimize foliar uptake of herbicides.

At each site, there were 3 different planting treatments per sub-subplot. Two seed mixtures, grass mixture only or grass and legume mixture, were planted in separate sub-subplots, and no species were planted in the third sub-subplot. Equal numbers of pure live seed of each species were included in each mixture to achieve a

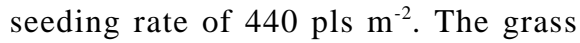
species in the grass or grass and legume mixtures were big bluestem, indiangrass, switchgrass, little bluestem [Schizachyrium scoparium (Michx.) Nash], and sideoats grama [Bouteloua curtipendula (Michx.) Torr.]. Legumes in the grass and legume mixture were leadplant [Amorpha canescens (Nutt.) Pursh], Illinois bundleflower [Desmanthus illinoensis (Michx.) MacM.], and purple prairieclover (Petalostemum purpurea Vent.). Seed mixtures were planted directly into the sod with no tillage on 11 April 1996 at Mason City and 26 April 1996 at Tilden using a 7 -row plot drill with an $18-\mathrm{cm}$ spacing between rows at a $1.3-\mathrm{cm}$ depth. Native

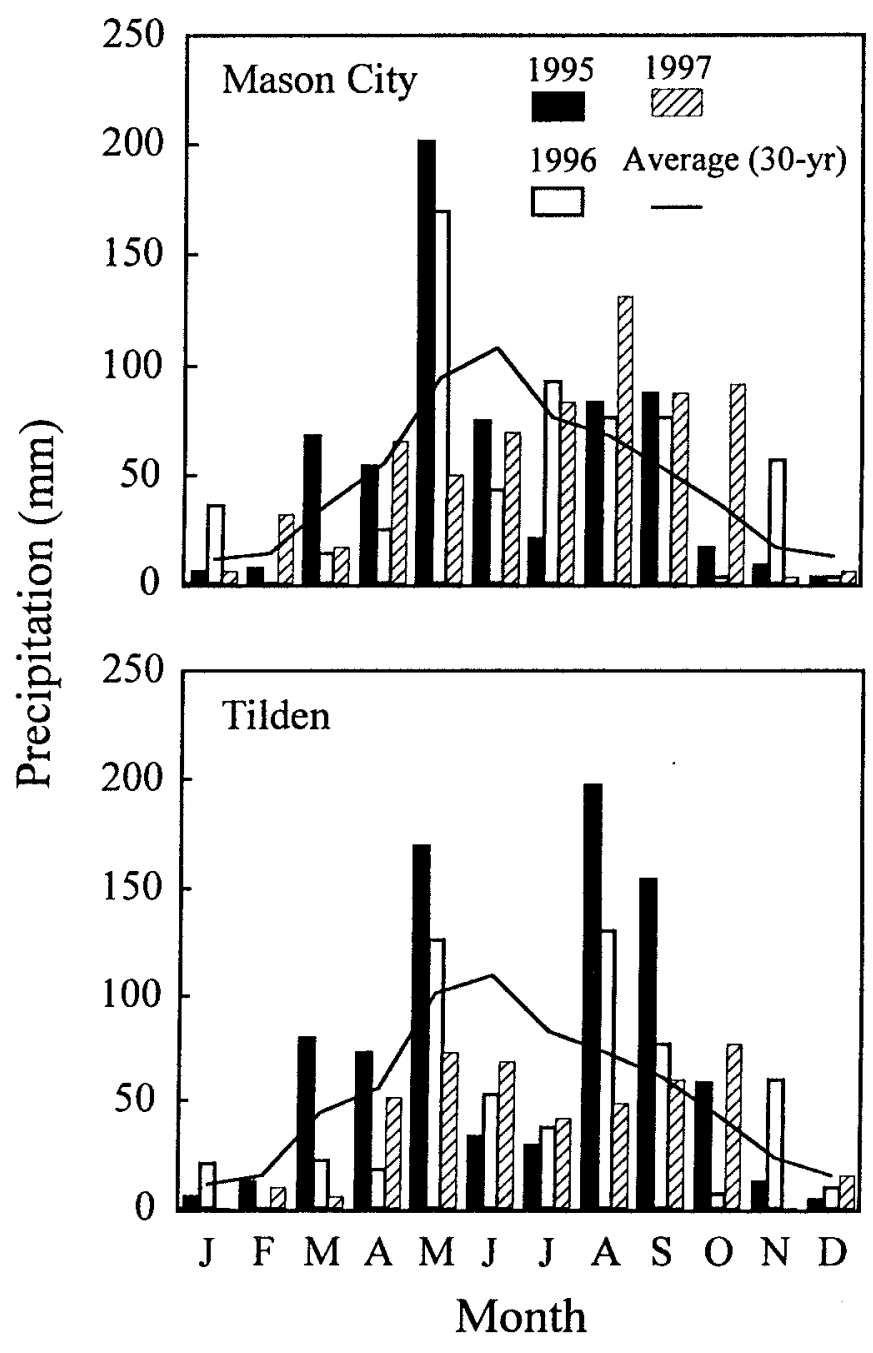

Fig. 1. Monthly precipitation for 1995 through 1997 and 30 year averages at Mason City and Tilden, Nebr. 
plant mixtures were planted without tillage to reduce soil erosion, soil water loss, and cost of seedbed preparation.

Frequency and herbage dry matter yield were measured between 14 and 16 months after planting. Measurements were taken the year after planting because establishment of perennial plants from seed is best determined after plants have survived a period of dormancy during the winter (Cook and Stubbendieck 1986). Both sites were burned in mid-spring 1997 to reduce interference of standing dead herbage with vegetation sampling.

Frequency was measured because it integrates pattern and abundance (Goldsmith and Harrison 1976), 2 important attributes when determining planted species establishment. Frequencies were determined in mid-June 1997 using a 90by $90-\mathrm{cm}\left(0.81 \mathrm{~m}^{2}\right)$ metal frame partitioned into a grid of twenty-five, 18- by $18-\mathrm{cm}$, cells. The frame was placed over the center 5 rows at 2 locations within each subplot. Presence or absence of a seeded grass or legume in each cell within the frame was recorded. Frequency within each frame was calculated by dividing the number of cells that contained at least 1 seeded species by 25 and then multiplying by 100 to convert the calculated proportion to a percentage. For this study, a threshold frequency above which establishment of the planted grasses was considered successful was determined. Launchbaugh and Owensby (1970) reported that $>10$ plants $\mathrm{m}^{-2}$ were needed for successful grass establishment in the central Great Plains. We estimated that a planted grass frequency of $32 \%\left(\geq_{-} 1\right.$ grass plant in 8 of the 25 cells within the grid used to determine frequency) was about equivalent to 10 plants $\mathrm{m}^{-2}$. This is a conservative estimate, since it is based on the presence of only 1 seeded grass plant in each of 8 cells within the frequency grid.

Dry matter yield of selected components of the vegetation and leafy spurge shoot density were determined in early August 1997. Dry matter yields were determined by harvesting vegetation within two, 0.25 $\mathrm{m}^{2}$ quadrats within each sub-subplot. Vegetation within each quadrat was clipped to a 2-cm stubble height, separated, oven-dried at $60^{\circ} \mathrm{C}$ to a constant weight, and weighed. Vegetation was separated into the following categories: big bluestem; switchgrass; indiangrass; little bluestem; sideoats grama; purple prairieclover; leadplant; Illinois bundleflower; leafy spurge; warm-season grasses (not including planted grasses); cool-season grasses; and forbs (not including planted legumes or leafy spurge). Leafy spurge density was determined by recording the number of live shoots emerging from the soil surface within quadrats placed in each sub-subplot during harvest.

Data from each site were analyzed separately using the general linear model procedure (SAS 1996). Frequency, density, and yield data were tested by analysis of variance using a split-split plot model. Response variables were analyzed within site because several variables had significant $(\mathrm{P} \leq 0.05)$ site interactions and heterogeneous error variances as indicated by Hartley's F-max test (Hartley 1950). Planted species and leafy spurge yield data were log transformed (Lentner and Bishop 1993). Data from significant $(\mathrm{P} \leq 0.05)$ highest order interactions are presented with means separated using Fisher's- protected LSD $($ alpha $=0.05)($ Ott 1977).

\section{Results and Discussion}

Annual precipitation at National Oceanographic and Atmospheric Administration stations within $15 \mathrm{~km}$ of the study sites during 1995, 1996, and 1997 ranged from 2 to $10 \%$ above the 30year average near Mason City and from $30 \%$ below average to $29 \%$ above average near Tilden (Fig. 1). April through August encompasses the time that the perennial native grasses and legumes were planted and period of peak production of the various vegetation components. Cumulative precipitation from April through August 1996 near Mason City was $408 \mathrm{~mm}$ and near Tilden was $368 \mathrm{~mm}$. Cumulative precipitation was 401 and $286 \mathrm{~mm}$ at Mason

Table 1. Leafy spurge density and yield at rangeland sites near Mason City and Tilden, Nebr. in August 1997 that were treated with herbicides, burned or mowed, and seeded with grass or grass and legume mixtures. ${ }^{1,2}$

\begin{tabular}{|c|c|c|c|c|c|c|}
\hline \multirow[b]{2}{*}{ Herbicide } & \multicolumn{2}{|c|}{ Rate } & \multicolumn{2}{|c|}{ Mason City } & \multicolumn{2}{|c|}{ Tilden } \\
\hline & Fall & $\overline{\text { Spring }}$ & Density & Yield $^{3}$ & Density & Yield $^{3}$ \\
\hline & & $\left.a^{-1}\right)$ & $\left(\right.$ no. $\mathrm{m}^{-2}$ ) & $\left(\mathrm{kg} \mathrm{ha}^{-1}\right)$ & $\left(\right.$ no. $\left.\mathrm{m}^{-2}\right)$ & $\left(\mathrm{kg} \mathrm{ha}^{-1}\right)$ \\
\hline Non-Treated & 0 & 0 & 147 & $340 \mathrm{a}$ & 117 & $240 \mathrm{a}$ \\
\hline Glyphosate & 1600 & 0 & 125 & $250 \mathrm{~b}$ & 97 & $150 \mathrm{a}$ \\
\hline $\begin{array}{l}\text { Imazapic + } \\
\text { glyphosate }\end{array}$ & $\begin{array}{c}140 \\
1600\end{array}$ & $\begin{array}{l}0 \\
0\end{array}$ & 82 & $120 \mathrm{c}$ & 14 & $60 \mathrm{~b}$ \\
\hline $\begin{array}{l}\text { Imazapic + } \\
\text { glyphosate }\end{array}$ & $\begin{array}{c}140 \\
1600\end{array}$ & $\begin{array}{r}70 \\
0\end{array}$ & 59 & $100 \mathrm{c}$ & 4 & $10 \mathrm{c}$ \\
\hline $\begin{array}{l}\text { Imazapic + } \\
\text { glyphosate }\end{array}$ & $\begin{array}{c}210 \\
1600\end{array}$ & $\begin{array}{l}0 \\
0\end{array}$ & 62 & $120 \mathrm{c}$ & 8 & $10 \mathrm{c}$ \\
\hline $\begin{array}{l}\text { Imazapic + } \\
\text { glyphosate }\end{array}$ & $\begin{array}{c}210 \\
1600\end{array}$ & $\begin{array}{r}70 \\
0\end{array}$ & 34 & $50 \mathrm{c}$ & 1 & $0 \mathrm{~d}$ \\
\hline $\operatorname{LSD}_{(0.05)}$ & & & 65 & - & 22 & - \\
\hline
\end{tabular}

${ }^{3}$ Herbicides were applied in October 1995 (Fall) and June 1996 (Spring). Burn and mow treatments were applied and grass and grass and legume mixtures were planted in April 1996.

Measured attributes are averaged across burn and mow treatments and planting treatments.

${ }^{3}$ Means followed by the same letter within a column are not significantly different $(\mathrm{P} \leq 0.05)$. Non-transformed means are presented, but mean separation test is based on analysis of log transformed data. 
Table 2. Frequency of planted native grasses (NG) and purple prairieclover (PPC) in June 1997 at rangeland sites near Mason City and Tilden, Nebr. that were treated with herbicides, burned (B) or mowed (M), and seeded with grass (G) or grass and legume mixtures (GL). ${ }^{1}$

\begin{tabular}{|c|c|c|c|c|c|c|c|c|c|c|}
\hline \multirow[b]{4}{*}{ Herbicide } & & & \multirow{2}{*}{\multicolumn{3}{|c|}{ Mason City }} & \multicolumn{5}{|c|}{ Tilden } \\
\hline & \multirow{2}{*}{\multicolumn{2}{|c|}{ Rate }} & & & & & & & & \multirow[b]{3}{*}{$\mathrm{PPC}^{3}$} \\
\hline & & & \multicolumn{2}{|c|}{$\mathrm{NG}^{2}$} & \multirow[b]{2}{*}{$\mathrm{PPC}^{3}$} & \multicolumn{2}{|c|}{ B } & \multicolumn{2}{|c|}{$\mathrm{M}$} & \\
\hline & Fall & $\overline{\text { Spring }}$ & B & $\bar{M}$ & & $\mathrm{G}$ & GL & $\bar{G}$ & GL & \\
\hline & \multicolumn{2}{|c|}{$\left(\mathrm{g}\right.$ a.i. ha $\left.^{-1}\right)$} & ------- & - & -----. & 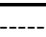 & $-n$ & - & ---- & --. \\
\hline Non-Treated & 0 & 0 & 0 & 1 & 0 & 0 & 1 & 0 & 0 & 0 \\
\hline Glyphosate & 1600 & 0 & 0 & 11 & 4 & 33 & 51 & 33 & 33 & 4 \\
\hline $\begin{array}{l}\text { Imazapic + } \\
\text { glyphosate }\end{array}$ & $\begin{array}{c}140 \\
1600\end{array}$ & $\begin{array}{l}0 \\
0\end{array}$ & 34 & 69 & 26 & 79 & 29 & 58 & 61 & 11 \\
\hline $\begin{array}{l}\text { Imazapic + } \\
\text { glyphosate }\end{array}$ & $\begin{array}{c}140 \\
1600\end{array}$ & $\begin{array}{c}70 \\
0\end{array}$ & 45 & 73 & 20 & 57 & 63 & 68 & 45 & 11 \\
\hline $\begin{array}{l}\text { Imazapic + } \\
\text { glyphosate }\end{array}$ & $\begin{array}{c}210 \\
1600\end{array}$ & $\begin{array}{l}0 \\
0\end{array}$ & 48 & 63 & 18 & 65 & 63 & 49 & 53 & 12 \\
\hline $\begin{array}{l}\text { Imazapic + } \\
\text { glyphosate }\end{array}$ & $\begin{array}{c}210 \\
1600\end{array}$ & $\begin{array}{c}70 \\
0\end{array}$ & 53 & 68 & 19 & 69 & 50 & 61 & 59 & 15 \\
\hline $\operatorname{LSD}_{(0.05)}$ & & & ----- & & 8 & & - & & ----- & 8 \\
\hline
\end{tabular}

Herbicides were applied in October 1995 (Fall) and June 1996 (Spring). Burn and mow treatments were applied and grass and grass and legume mixtures were planted in April 1996.

${ }^{2}$ Native grass frequencies are averaged across grass and grass and legume mixture treatments.

${ }^{3}$ Purple prairieclover frequencies are averaged across burn and mow treatments.

variations in temperature extremes and soil water loss, compared with areas where the residue was consumed by fire.

At Tilden, native grass frequency was influenced by the interaction of herbicide, residue, and planting treatments (Table 2). Native grass frequencies where no herbicide was applied were $1 \%$ or less compared with frequencies that usually exceeded $32 \%$ where glyphosate was applied with or without imazapic. In a few instances, grass frequencies were lower where the grass and legume mixture had been planted compared with where only the grass mixture was planted. This could have been because more grass seeds were planted in the grass mixture compared with the grass and legume mixture. The

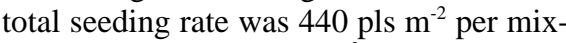
ture, which was $88 \mathrm{pls} \mathrm{m}^{-2}$ for each of the 5 species planted in the grass mixture and $55 \mathrm{pls} \mathrm{m}^{-2}$ for each of the 8 species ( 5 grasses and 3 legumes) in the grass and legume mixture.

Imazapic applied with glyphosate improved combined yields of the planted species in the grass mixture or grass and legume mixture at both study sites (Tables 3 and 4). Combined yields ranged from 3.0 to $4.6 \mathrm{Mg} \mathrm{ha}^{-1}$ at Mason City and 1.9 to $3.0 \mathrm{Mg} \mathrm{ha}^{-1}$ at Tilden where imazapic was applied with glyphosate. In contrast, yields were $0.3 \mathrm{Mg} \mathrm{ha}^{-1}$ at Mason City and $1.2 \mathrm{Mg} \mathrm{ha}^{-1}$ at Tilden where only glyphosate was applied, and $0.3 \mathrm{Mg} \mathrm{ha}^{-1}$ or less at both sites where no herbicide was applied. Big bluestem and indiangrass were the dominant grasses in the planted stands. They comprised more than $60 \%$ of the combined yields where imazapic was applied with glyphosate at both sites. Big bluestem, indiangrass, and little bluestem yields at Mason City were greater where imazapic was applied than where no herbicide or only glyphosate was applied (Table 3). Sideoats grama and switchgrass yields were very low, regardless of herbicide treatment. Sideoats grama yields may have been low because this mid-grass is not as productive and may not have been as competitive as the planted tallgrasses. Low yields of switchgrass may reflect its susceptibility to imazapic as reported by Masters et al. (1996). At Tilden, indiangrass yields were greatest where imazapic was applied with glyphosate, whereas there was no difference in big bluestem yields where glyphosate was applied with or without imazapic (Table 4). When assessing yields of the various species within the planted mixtures it is important to note that these data reflect species composition early in the development of these plant stands. The distribution and composition of species will likely change as the stands mature under prevailing climate and management regimes.

Purple prairieclover was the only legume to persist 14 months after planting at both study sites. Frequency of purple prairieclover was $\geq 18 \%$ and $11 \%$ where

Table 3. Yield of big bluestem (BB), indiangrass (IN), little bluestem (LB), sideoats grama (SG), switchgrass (SW), and purple prairieclover (PPC) and combined yield of grass (G) and grass and legume (GL) mixtures in August 1997 at a rangeland site near Mason City, Nebr. that was treated with herbicides, burned $(B)$ or mowed $(M)$, and seeded with grass or grass and legume mixtures. ${ }^{1,2}$

\begin{tabular}{|c|c|c|c|c|c|c|c|c|}
\hline \multirow[b]{2}{*}{ Herbicide } & \multicolumn{2}{|c|}{ Rate } & \multicolumn{5}{|c|}{ Planted species ${ }^{3}$} & \multirow[b]{2}{*}{ Combined yield ${ }^{4}$} \\
\hline & Fall & $\overline{\text { Spring }}$ & $\overline{\mathrm{BB}}$ & IN & $\mathrm{LB}$ & $\mathrm{SG}+\mathrm{SW}$ & $\overline{\mathrm{PPC}}$ & \\
\hline & \multicolumn{2}{|c|}{$\left(\mathrm{g}\right.$ a.i. $\left.\mathrm{ha}^{-1}\right)$} & ------. & ----- & $\begin{array}{c}---- \\
---1\end{array}$ & $\left(\mathrm{Mg} \mathrm{ha}^{-1}\right)$ & ------ & 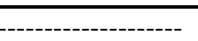 \\
\hline Non-Treated & 0 & 0 & $0 \mathrm{a}$ & $0 \mathrm{a}$ & $0 \mathrm{a}$ & $0 \mathrm{a}$ & $0 \mathrm{a}$ & $0 \mathrm{a}$ \\
\hline Glyphosate & 1600 & 0 & $0.1 \mathrm{~b}$ & $0.1 \mathrm{~b}$ & $0 \mathrm{a}$ & $0 \mathrm{a}$ & $0 \mathrm{a}$ & $0.3 \mathrm{~b}$ \\
\hline $\begin{array}{l}\text { Imazapic + } \\
\text { glyphosate }\end{array}$ & $\begin{array}{c}140 \\
1600\end{array}$ & $\begin{array}{l}0 \\
0\end{array}$ & $0.8 \mathrm{c}$ & $1.6 \mathrm{c}$ & $0.3 \mathrm{~b}$ & $0.1 \mathrm{a}$ & $0.6 \mathrm{~b}$ & $3.0 \mathrm{c}$ \\
\hline $\begin{array}{l}\text { Imazapic + } \\
\text { glyphosate }\end{array}$ & $\begin{array}{c}140 \\
1600\end{array}$ & $\begin{array}{c}70 \\
0\end{array}$ & $0.9 \mathrm{c}$ & $2.1 \mathrm{c}$ & $0.3 \mathrm{~b}$ & $0 \mathrm{a}$ & $0.2 \mathrm{~b}$ & $3.5 \mathrm{c}$ \\
\hline $\begin{array}{l}\text { Imazapic + } \\
\text { glyphosate }\end{array}$ & $\begin{array}{c}210 \\
1600\end{array}$ & $\begin{array}{l}0 \\
0\end{array}$ & $0.8 \mathrm{c}$ & $1.8 \mathrm{c}$ & $0.5 \mathrm{~b}$ & $0 \mathrm{a}$ & $0.3 \mathrm{~b}$ & $3.3 \mathrm{c}$ \\
\hline $\begin{array}{l}\text { Imazapic + } \\
\text { glyphosate }\end{array}$ & $\begin{array}{c}210 \\
1600\end{array}$ & $\begin{array}{c}70 \\
0\end{array}$ & $1.1 \mathrm{c}$ & $2.9 \mathrm{c}$ & $0.3 \mathrm{~b}$ & $0 \mathrm{a}$ & $0.4 \mathrm{~b}$ & $4.6 \mathrm{c}$ \\
\hline
\end{tabular}

${ }^{1}$ Herbicides were applied in October 1995 (Fall) and June 1996 (Spring). Burn or mow treatments were applied and grass or grass and legume mixtures were planted in April 1996.

${ }^{2}$ Means followed by the same letter within a column are not significantly different $(\mathrm{P} \leq 0.05)$. Non-transformed means are presented, but mean separation test is based on analysis of transformed data.

${ }^{3}$ Planted grass yields are averaged across planted grass and grass and legume mixtures and burn and mow treatments. Prairieclover yields are averaged across burn and mow treatments.

${ }^{4}$ Combined yields are averaged across planted grass and grass and legume mixtures and burn and mow treatments. 
Table 4. Yield of big bluestem (BB), indiangrass (IN), little bluestem (LB), sideoats grama (SG), switchgrass (SW), and purple prairieclover (PPC) and combined yield of grass (G) and grass and legume (GL) mixtures in August 1997 at a rangeland site near Tilden, Nebr. that was treated with herbicides, burned (B) or mowed (M), and seeded with grass or grass and legume mixtures. $^{1,2}$

\begin{tabular}{|c|c|c|c|c|c|c|c|}
\hline \multirow[b]{2}{*}{ Herbicide } & \multicolumn{2}{|c|}{ Rate } & \multicolumn{4}{|c|}{ Planted species ${ }^{3}$} & \multirow[b]{2}{*}{ Combined yield ${ }^{4}$} \\
\hline & Fall & Spring & $\overline{\mathrm{BB}}$ & IN & $\begin{array}{c}\mathrm{SG}+\mathrm{LB} \\
+\mathrm{SW}\end{array}$ & PPC & \\
\hline & \multicolumn{2}{|c|}{$\left(\mathrm{g}\right.$ a.i. $\left.\mathrm{ha}^{-1}\right)$} & \multicolumn{5}{|c|}{$\left(\mathrm{Mg} \mathrm{ha}^{-1}\right)$} \\
\hline Non-Treated & 0 & 0 & $0 \mathrm{a}$ & $0.1 \mathrm{a}$ & $0.2 \mathrm{a}$ & $0 \mathrm{a}$ & $0.3 \mathrm{a}$ \\
\hline Glyphosate & 1600 & 0 & $0.4 \mathrm{~b}$ & $0.2 \mathrm{a}$ & $0.5 \mathrm{a}$ & $0.2 \mathrm{~b}$ & $1.2 \mathrm{~b}$ \\
\hline $\begin{array}{c}\text { Imazapic + } \\
\text { glyphosate }\end{array}$ & $\begin{array}{c}140 \\
1600\end{array}$ & $\begin{array}{l}0 \\
0\end{array}$ & $0.5 \mathrm{~b}$ & $0.9 \mathrm{~b}$ & $0.4 \mathrm{a}$ & $0.1 \mathrm{~b}$ & $1.9 \mathrm{c}$ \\
\hline $\begin{array}{c}\text { Imazapic }+ \\
\text { glyphosate }\end{array}$ & $\begin{array}{c}140 \\
1600\end{array}$ & $\begin{array}{c}70 \\
0\end{array}$ & $0.8 \mathrm{~b}$ & $1.3 \mathrm{~b}$ & $0.7 \mathrm{a}$ & $0.3 \mathrm{~b}$ & $3.0 \mathrm{c}$ \\
\hline $\begin{array}{c}\text { Imazapic + } \\
\text { glyphosate }\end{array}$ & $\begin{array}{c}210 \\
1600\end{array}$ & $\begin{array}{l}0 \\
0\end{array}$ & $0.6 \mathrm{~b}$ & $0.9 \mathrm{~b}$ & $0.8 \mathrm{a}$ & $0.2 \mathrm{~b}$ & $2.4 \mathrm{c}$ \\
\hline $\begin{array}{c}\text { Imazapic + } \\
\text { glyphosate }\end{array}$ & $\begin{array}{c}210 \\
1600\end{array}$ & $\begin{array}{c}70 \\
0\end{array}$ & $0.7 \mathrm{~b}$ & $1.4 \mathrm{~b}$ & $0.5 \mathrm{a}$ & $0.2 \mathrm{~b}$ & $2.6 \mathrm{c}$ \\
\hline
\end{tabular}

${ }^{3}$ Herbicides were applied in October 1995 (Fall) and June 1996 (Spring). Burn or mow treatments were applied and grass or grass and legume mixtures were planted in April 1996.

${ }^{2}$ Means followed by the same letter within a column are not significantly different $(\mathrm{P} \leq 0.05)$. Non-transformed means are presented, but mean separation test is based on analysis of transformed data.

${ }^{3}$ Planted grass yields are averaged across planted grass and grass and legume mixtures and burn and mow treatments. Prairieclover yields are averaged across burn and mow treatments.

${ }^{4}$ Combined yields are averaged across planted grass and grass and legume mixtures and burn and mow treatments.

imazapic was applied with glyphosate at Mason City and Tilden, respectively (Table 2), compared with $4 \%$ or lower frequencies where no herbicide or only glyphosate was applied. Purple prairieclover yields were greater at both sites where herbicides had been applied and contributed at most $20 \%$ and usually less than $10 \%$ to the combined herbage yield (Tables 3 and 4). Illinois bundleflower was common at both sites within the first 3 months after planting, but did not persist. Leadplant was rarely observed during the study.

Successful establishment of only 1 of the 3 planted legume species in this study highlights potential problems using native legumes in rangeland revegetation programs. High cost, low availability, and variable quality of native legume seeds further constrain their use. Legumes may improve $\mathrm{N}$ availability in degraded rangeland ecosystems, while providing a sustainable and higher quality forage resource. Posler et al. (1993) found that certain legumes native to the central Great Plains, e.g., Illinois bundleflower, roundhead lespedeza (Lespedeza capitata Michx.), and catclaw sensitivebriar [Mimosa quadrivalvis var. nuttallii (DC.) LS. Beard ex Barneby], improved forage yield and crude protein content when seeded with native warm-season grasses. Clearly, more information is needed about native legume compatibility with warmseason grasses, contribution to nitrogen fixation, seed production, and establishment methods before they can be recommended for use in rangeland improvement strategies. ranged from 0.6 to $0.8 \mathrm{Mg} \mathrm{ha}^{-1}$ where imazapic was applied with glyphosate and were $<0.3 \mathrm{Mg} \mathrm{ha}^{-1}$ where no herbicide or only glyphosate was applied. Yields of the warm-season grasses were less than 0.2 $\mathrm{Mg} \mathrm{ha} \mathrm{H}^{-1}$ where grass or grass and legume mixtures were planted and were $1.3 \mathrm{Mg}$ $\mathrm{ha}^{-1}$ where no species were planted. This response of the resident warm-season grasses resulted from remnant native grasses at Tilden that were released after leafy spurge and other resident vegetation was suppressed by the herbicides.

Total vegetation yield (planted species yield + resident vegetation yield) responses to the treatments varied by site. At Mason City, the interaction of herbicide and planting treatments was significant $(\mathrm{P}$ $\leq 0.05$ ) (Table 5). Yields, ranging from 2.0 to $2.7 \mathrm{Mg} \mathrm{ha}^{-1}$, were similar across planting treatments where no herbicide or only glyphosate was applied. In contrast, total yields from imazapic-treated areas were greater and ranged from 4.1 to $7.0 \mathrm{Mg} \mathrm{ha}^{-1}$ where grass or grass and legume mixtures were planted, while yields where no species were planted ranged from 2.3 to $3.2 \mathrm{Mg} \mathrm{ha}^{-1}$. These substantive yield increases provide evidence for the suppression of existing vegetation by imazapic applied with glyphosate, which facilitated establishment of the planted species. Moreover, increased dry matter yield where the planted grasses were successfully established demonstrates that the productivity of the leafy spurge-dominated plant community was far lower than the potential for the site.

Total vegetation yield at Tilden was influenced by herbicides, but not by plant-

Table 5. Total yield of vegetation on rangeland sites near Mason City and Tilden, Nebr. in August 1997 that were treated with herbicides, burned or mowed, seeded with grass (G) or grass and legume mixtures (GL) or not seeded (NS).

\begin{tabular}{|c|c|c|c|c|c|c|}
\hline \multirow[b]{2}{*}{ Herbicide } & \multicolumn{2}{|c|}{ Rate } & \multicolumn{4}{|c|}{ Mason City ${ }^{2}$} \\
\hline & Fall & Spring & G & GL & NS & Tilden $^{2}$ \\
\hline & \multicolumn{2}{|c|}{ (g a.i. ha $\left.{ }^{-1}\right)$} & ---- & - & --- & --------. \\
\hline Non-Treated & 0 & 0 & 2.1 & 2.0 & 2.3 & 1.1 \\
\hline Glyphosate & 1600 & 0 & 2.3 & 2.4 & 2.7 & 2.3 \\
\hline \multirow{2}{*}{$\begin{array}{l}\text { Imazapic + } \\
\text { glyphosate }\end{array}$} & 140 & 0 & 4.1 & 5.0 & 2.4 & 3.0 \\
\hline & 1600 & 0 & & & & \\
\hline \multirow{2}{*}{$\begin{array}{l}\text { Imazapic + } \\
\text { glyphosate }\end{array}$} & 140 & 70 & 4.7 & 5.8 & 3.2 & 4.0 \\
\hline & 1600 & 0 & & & & \\
\hline \multirow{2}{*}{$\begin{array}{l}\text { Imazapic + } \\
\text { glyphosate }\end{array}$} & 210 & 0 & 4.8 & 5.1 & 2.7 & 3.2 \\
\hline & 1600 & 0 & & & & \\
\hline \multirow{2}{*}{$\begin{array}{l}\text { Imazapic + } \\
\text { glyphosate }\end{array}$} & 210 & 70 & 7.0 & 4.7 & 3.0 & 3.3 \\
\hline & 1600 & 0 & & & & \\
\hline \multicolumn{3}{|l|}{ LSD (0.05) } & -- & --1. & . & 0.9 \\
\hline
\end{tabular}

${ }^{1}$ Herbicides were applied in October 1995 (Fall) and June 1996 (Spring). Burn and mow treatments were applied and grass and grass and legume mixtures were planted in April 1996.

${ }_{2}^{2}$ Measured attributes are averaged across burn and mow treatments.

${ }^{3}$ Measured attributes are averaged across planting treatments and burn and mow treatments. 
ing treatments. Total yields where imazapic was applied with glyphosate ranged from 3.0 to $4.0 \mathrm{Mg} \mathrm{ha}^{-1}$ compared with a yield of only $1.1 \mathrm{Mg} \mathrm{ha}^{-1}$ where no herbicide was applied (Table 5). Total yields were increased where imazapic was applied at $70 \mathrm{~g}$ a.i. ha ${ }^{-1}$ in June 1996 compared to yields where glyphosate was applied in October 1995. Total yields on areas treated with imazapic at $140 \mathrm{~g}$ a.i. $\mathrm{ha}^{-1}$ combined with glyphosate in October 1995 were greatest where imazapic was applied again in June 1996. Perhaps suppression of certain species in the resident vegetation caused by the June 1996 imazapic treatment favored some of the planted or resident species. The reasons for this positive response were not evident from yields of the planted species (Tables 3 and 4) or resident vegetation components.

Imazapic and glyphosate were essential components of treatments applied before planting to improve establishment of native grass and legume stands on the leafy spurge-infested grasslands evaluated in this study. Applying these herbicides together reduced leafy spurge and other resident vegetation, which facilitated establishment of the planted native species in less than 2 years. Planted species yields were increased substantially and leafy spurge density and yield were reduced by imazapic applied with glyphosate compared with glyphosate applied alone or no herbicide. Increases in total yields where native species were seeded at Mason City and where imazapic was applied with glyphosate at Tilden indicate that the inherent productivity of the site was not being fully expressed by the plant community dominated by leafy spurge, Kentucky bluegrass, and smooth bromegrass. These yield increases reflect the considerable contribution of the warm-season native plants, which appeared to use site resources more efficiently than the cool-season plants that dominated the leafy spurge-infested communities. This strategy took less than 2 years to substantively improve the forage resource and reduce leafy spurge. These plant stands should be evaluated over several years to determine changes in species composition and productivity, and rate of leafy spurge recovery.

Established mixtures of native species have the potential to more fully utilize grassland resources and preempt resource use by leafy spurge and the other less desirable species. By maximizing resource capture, the more diverse reestablished grassland community could be more resistant to invasion by less desirable species. Tilman et al. (1996) determined that plant productivity and nitrogen use were greater in more diverse plant species mixtures than less diverse mixtures. This supports the concept that differences in resource use by multiple plant species allows more diverse plant communities to more fully use resources than less diverse plant communities and improve overall productivity (Frank and McNaughton 1991, McNaughton 1993, Naeem et al. 1994). More diverse grassland communities also should be more resilient (Tilman and Downing 1994) and better able to sustain stable ecosystem processes over a range of disturbances, e.g., grazing, fire, and periodic droughts, and return to a desirable state once disturbances moderate.

Our goal was to provide rangeland managers with strategies that extend beyond controlling undesirable vegetation and lead to restoring degraded rangeland communities by reintroducing desirable native plant mixtures. Establishing mixtures of desirable species, as demonstrated in this study, represents an important step in the process of recapturing the productive potential of leafy spurge-infested sites in the central Great Plains. Once these desirable species establish, management systems must be used that shift the competitive advantage to desirable species and away from invasive species. Chemical and biological controls will continue to be important components of these management systems because of the continued threat leafy spurge will pose to these restored communities. The strategy developed in this study has the potential to provide the means to redirect the successional trajectory of the leafy spurge-infested communities towards a more desirable community comprised of native prairie flora with improved carrying capacity and native plant diversity, and decreased leafy spurge abundance.

\section{Literature Cited}

Beran, D.D., R.E. Gaussoin, and R.A. Masters. 1999a. Native wildflower establishment with imidazolinone herbicides. HortSci. 34:283-286.

Beran, D.D., R.A. Masters, and R.E. Gaussoin. 1999b. Grassland legume establishment with imazethapyr and imazapic. Agron. J. 91:592-596.

Beran, D.D., R.A. Masters, R.E. Gaussoin, F. Rivas-Pantoja. 2000. Establishment of big bluestem and Illinois bundleflower mixtures with imazapic and imazethapyr. Agron. J. 92:460-465.

Belcher, J.W. and S.D. Wilson. 1989. Leafy spurge and the species composition of a mixed-grass prairie. J. Range Manage. 42:172-175.
Cook, C.W. and J.L. Stubbendieck. 1986. Range research: Basic problems and techniques. Soc. for Range Manage., Denver, Colo.

Dunn, P.H. 1979. The distribution of leafy spurge (Euphorbia esula) and other weedy Euphorbia spp. in the United States. Weed Sci. 27:509-516.

Ferrell, M.A., T.D. Whitson, D.W. Koch, and A.E. Gade. 1998. Leafy spurge (Euphorbia esula) control with several grass species. Weed Technol. 12:374-380.

Frank, D.A. and S.J. McNaughton. 1991. Stability increases with diversity in plant communities: empirical evidence from the 1988 Yellowstone drought. Oikos 62:360-362.

Goldsmith, F. B. and C. M. Harrison. 1976. Description and analysis of vegetation. p. 85-155 In S. B. Chapman, ed. Methods in plant ecology. Halstead Press, New York, N.Y.

Hansen, R.W., R.D. Richard, P.E. Parker, and L.E. Wendel. 1997. Distribution of biological control agents of leafy spurge (Euphorbia esula L.) in the United States: 1988-1996. Biol. Control 10:129-142.

Harris, P., P. H. Dunn, D. Schroeder, and R. Vonmoos. 1985. Biological control of leafy spurge in North America. p. 79-92 In: A. K. Watson, ed. Leafy Spurge Monograph No. 3. Weed Sci. Soc. Amer. Champaign, Ill.

Hartley, H.O. 1950. The maximum $F$-ratio as a short-cut test for heterogeneity of variance. Biometrika. 37:308-312.

Kirby, D. R. and R. B. Carlson. 1998. Leafy spurge control with flea beetles (Aphthona spp.). Proc. Western Soc. Weed Sci. 51:130.

Landgraf, B.K., P.K. Fay, and K.M. Havstad. 1984. Utilization of leafy spurge (Euphorbia esula) by sheep. Weed Sci. 32:348-352.

Launchbaugh, J.L. and C.E. Owensby. 1970. Seeding rate and first year stand relationships for six native grasses. J. Range Manage. 23:414-417.

Lentner, M. and T. Bishop. 1993. Experimental design and analysis. Valley Book Co., Blacksburg, Virg.

Lym, R.G. 1998. The biology and integrated management of leafy spurge (Euphorbia esula) on North Dakota rangeland. Weed Technol. 12:367-373.

Lym, R.G. and D.R. Kirby. 1987. Cattle foraging behavior in leafy spurge (Euphorbia esula)-infested rangeland. Weed Technol. 1:314-318.

Lym, R.G. and C.G. Messersmith. 1985. Leafy spurge control with herbicides in North Dakota: 20 year summary. J. Range Manage. 38:149-154.

Lym, R.G. and D.A. Tober. 1997. Competitive grasses for leafy spurge (Euphorbia esula) reduction. Weed Technol. 11:787-792.

Lym, R.G., K.K. Sedivec, and D.R. Kirby. 1997. Leafy spurge control with angora goats and herbicides. J. Range Manage. 50:123-128.

Masters, R.A. and S.J. Nissen. 1998. Revegetating leafy spurge (Euphorbia esula 
L.)-infested grasslands with native tallgrasses. Weed Technol. 12:381-390.

Masters, R.A., D.D. Beran, and F. RivasPantoja. 1998. Leafy spurge (Euphorbia esula L.) response to AC 263,222 . Weed Technol. 12:602-609.

Masters R.A., R. Stritzke, and S.S. Waller. 1990. How to conduct a prescribed burn and prescribed burning checklist. Nebr. Coop. Ext. Serv. EC 90-121.

Masters, R.A., S.J. Nissen, R.E. Gaussoin, D.D. Beran, and R.N. Stougaard. 1996. Imidazolinone herbicides improve restoration of Great Plains grasslands. Weed Technol. 10:392-403.

McNaugton, S.J. 1993. Biodiversity and function of grazed ecosystems. p. 311-382 In: Schulze, E.D. and H.A. Mooney, eds. Biodiversity and ecosystem function. Springer-Verlag, Berlin.

Naeem, S, L.J. Thompson, S.P. Lawler, J.H. Lawton, and R.M. Woodfin. 1994. Declining biodiversity can alter the performance of ecosystems. Nature 368:734-737.
Ott, L. 1977. An introduction to statistical methods and data analysis. Duxbury Press, Belmont, Calif.

Posler, G.L., A.W. Lenssen, and G.L. Fine. 1993. Forage yield, quality, compatibility and persistence of warm-season grasslegume mixtures. Agron. J. 85:554-560

Raju, M.V.S. 1985. Morphology and anatomy of leafy spurge. p. 26-41. In: Watson, A.K. (ed.) Leafy spurge. Weed Sci. Soc. Monogr. 3. Champaign, Ill.

Rivas-Pantoja, F., R.A. Masters, and D.D. Beran. 1997. Influence of planting date and herbicides on native tallgrass establishment. Soc. Range Manage., Rapid City, S.D. Abstr. p. 63.

SAS Institute, Inc. 1996. SAS user's guide: statistics. Version 6 ed. SAS Inst., Cary, N.C.

Scifres, C.J. 1987. Decision-analysis approach to brush management planning: Ramifications for integrated range resources management. J. Range Manage. 40:482-490.

Selleck, G.W., R.T. Coupland, and C. Frankton. 1962. Leafy spurge in Saskatchewan. Ecol. Monogr. 32:1-29.
Sheley, R.L., T.J. Svejcar, and B.D. Maxwell. 1996. A theoretical framework for developing successional weed managmeent strategies for rangeland. Weed Technol. 10:766-773.

Thompson, W.M., S.J. Nissen, and R.A. Masters. 1998. AC 263,222 absorption and fate in leafy spurge (Euphorbia esula). Weed Sci. 46:510-513.

Tilman, D. and J.A. Downing. 1994. Biodiversity and stability in grasslands. Nature 367:363-365.

Tilman, D., D. Wedin, and J. Knops. 1996. Productivity and sustainability influenced by biodiversity in grassland ecosystems. Nature 379:718-720.

Watson, A.K. 1985. Introduction-The leafy spurge problem. p. 1-7 In: Watson, A.K. (ed.) Leafy spurge. Weed Sci. Soc. Monogr. 3. Champaign, Ill. 